\title{
Characteristics of Slope Failures in Tropical Hill Slopes of South West India
}

\author{
Arish Aslam ${ }^{1}$, Sreekumar S ${ }^{2}$ \\ ${ }^{1}$ Research and Post Graduate Department of Geology and Environmental Science \\ Christ College, Irinjalakuda- 680125, India \\ ${ }^{2}$ Research and Post Graduate Department of Geology and Environmental Science \\ Christ College, Irinjalakuda- 680125, India
}

\begin{abstract}
The occurrence of rainfall induced slope failures in residual soil slopes is a common natural disaster encountered in many tropical regions. Furthermore factors such as hill slope, relative relief, attitude of joints, material properties of rocks, type of vegetation and land use practices make a hill slope vulnerable to slope failures. Its ferocity depends upon the material properties and thickness of the loose unconsolidated overburden formed by the weathering process. The triggering factor for the slope failures is found to be continuous heavy rainfall for a couple of days. The paper examines the mechanism of slope failures in hill ranges of Kerala state which lies in the south west part of Indian peninsula. The failure surface is identified and located from the field and its interaction with material properties and hill slope is critically examined. Highly weathered rock samples were collected from the failed areas for the determination of material property such as friction angle. Geometrical method is used for understanding the role of joints in the slope instability.
\end{abstract}

Keywords: Slope failures, Western Ghats, Rainfall Pattern, Discontinuities, Friction Angle

\section{Introduction}

Slope failures such as debris flows, landslides, slump often turn disastrous along the hill ranges of Kerala state in the southern parts peninsular India. The disaster often takes the lives of many people, damage settlements, infrastructure and acres of agricultural land. The debris resulted from the slide snap the communication arteries and damage power lines. The terrain is made of hard crystalline rocks of Precambrian age and shows intense chemical weathering due to humid tropical climate. The influence of rainfall on slope instability in Kerala Western Ghats has been established by earlier workers [13][5]. The torrential and incessant rains in localized areas are the immediate cause of most of landslide [7][9][10]. The natural factors like steep hill slope thickness of overburden, high precipitation, attitude of joints and lithology are determental factor, which cause failures [15][4][1][3][14]. The progressive weathering has resulted thick overburden ranging from 2 to 4 meters. The aim of this study is to understand the triggering factors of slope failures in selected sites.

\section{Study Area}

The detailed study of the following locations where slope failure occurred during different times in the Kerala State have been carried out (Table 1 and Figure 1).

Table 1: Locations of slope failures

\begin{tabular}{|c|c|}
\hline Locations & Latitude and Longitude \\
\hline Pasukkadavu (K01) & N 11039'54.86" E 0750 50' 39.51" \\
\hline Kakkayam(K02) & N 11033'24.9" E 750 54' 50.6" \\
\hline Chengara (M01) & 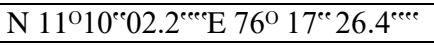 \\
\hline Akamala (T01) & 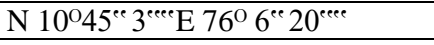 \\
\hline Kunjithanni (I01) & $\mathrm{N} 10^{\circ} 00^{\circ "} 49.1^{\prime \prime} \mathrm{E} 77^{\circ} 03^{\circ "} 42.5^{\text {ceec }}$ \\
\hline Methottimala(I02) & 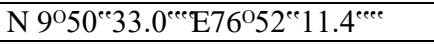 \\
\hline
\end{tabular}

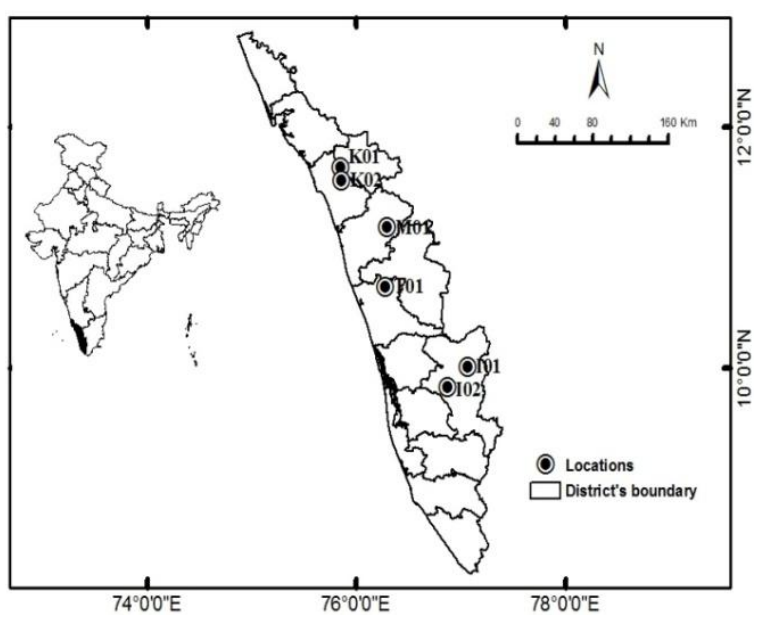

Figure 1 : Study Area

\section{Geology and Climate}

The Kerala region is an important segment of south Indian Precambrian terrain, where major units of the Archean continental crust, such as granulite, granites, gneisses and greenstones are preserved. The bulk of the rocks of Kerala, especially the granulites and associated gneisses belonging to Precambrian. Lateritisation is wide spread, thick blanket of laterite is found covering the hard rock. Lateritisation is also observed along the planes of weakness in hard rock"s such as fractures and joints.

The territory of Kerala falls within the realm of tropical climate and the wet period is due to the South west (June to September) and North east monsoon (October to December). The average annual rain fall in the highland region is generally above $300 \mathrm{~cm}$ and in some places receive far above this amount. Though shallow, disastrous mass wasting processes occur during these periods. 


\section{International Journal of Science and Research (IJSR) \\ ISSN (Online): 2319-7064}

Index Copernicus Value (2013): 6.14 | Impact Factor (2014): 5.611

\section{Methodology}

A detailed investigation was carried out in the failed areas immediately after the event. Friction angle, one of the important material properties of slope materials was determined in the Geotechnical laboratory. Geological data such as hill slope, relative relief, orientation of joints which acted as failure surface were collected from the site. Role of joints were evaluated by Back Analysis using geometrical methods [2]. Geometrical analysis was used in plotting the joint orientation data in an equal area net. Beta diagram for the profile are constructed from the joint orientation data. The circle representing the cone for the angle of internal friction is plotted. The trace of the great circle passing through the slope angle is also incorporated in the beta diagram. The type of failure is identified from the geometric analysis. Rainfall data for the period is collected from the rain guage station nearest to the location of the slide. The pattern and amount of rainfall that triggered the slope failures is critically examined.

\section{Results and Discussion}

General slope of the hill, attitude of the joints, thickness of overburden and nature of failure are documented from the affected areas. Friction angle of the slope material, height and relative relief are determined and provided in Table 2. The orientation of the stereo plot of set of joints and their relationship with general hill slope and angle of internal friction of rock at different locations are provided in the Figures 2 a, b, c and d.

\subsection{Pasukkadav (K01)}

Debris flow occurred on $4^{\text {th }}$ August 2004 in Pasukkadav which lies in Kozhikode district. Repeated slope failures have been observed in the area after every monsoon. Pasukkadav hill slope profile has a maximum elevation of $775 \mathrm{~m}$ and lowest elevation of $300 \mathrm{~m}$ from MSL. The crest has a length of $1.2 \mathrm{~km}$ and granitic gneiss forms they chief rock type of the area. The overburden consists of highly weathered rocks, boulders, laterites and colluvial debris. The thickness of the overburden ranges from $1 \mathrm{~m}$ to $3.1 \mathrm{~m}$. the terrain is characterized by isolated rocky tops with near vertical slopes. The general downward slope of the profile is $48^{\circ}$ towards east. Entire hill slope is under cultivation barring the rocky tip. The vegetation pattern includes mixed crops containing plantain, pepper, coconut and jack fruit trees. Four major joints traverses the profile with gapping ranges from $1 \mathrm{~cm}$ to $2 \mathrm{~cm}$. The failed surface has a dip 32 towards N 310. The scar of the slide has a crown with width $5 \mathrm{~m}$ and $1 \mathrm{~m}$ depth. The width of the scar increases up to $20 \mathrm{~m}$ and depth up to $1.5 \mathrm{~m}$ in the middle. Further downwards the width increase up to $30 \mathrm{~m}$ but become much shallower.

Friction angle determined as $48^{\circ}$. Prominent joints in the exposed failure area are $51^{\circ} \mathrm{N}\left(\mathrm{J}_{1}\right), 32{ }^{\circ} \mathrm{N} 90\left(\mathrm{~J}_{2}\right), 22^{\circ} \mathrm{N} 90$ $\left(\mathrm{J}_{3}\right)$ and $80^{\circ} \mathrm{N} 90\left(\mathrm{~J}_{4}\right) . \mathrm{J} 2$ and $\mathrm{J} 3$ are the potential slide surface along which the debris moved down slope (Figure $2 a)$. The friction angle reduced during rainy season and FOS reduced further and slope failure occurred.

\subsection{Kakkayam (K02)}

It is located in Kozhikode district of Kerala. Slope failures are reported in 2009 and 1984. Lithologically the slope consists of granitic gneiss. Minerologically it consist of $80 \%$ quartz and feldspar. Less weathered rock exposure is observed. The thickness of the overburden is 1.5 meters. It comes under reserve forest area. The rock is not well jointed. The maximum relief is calculated as $245 \mathrm{~m}$. The slope of the hill is $50^{\circ}$ towards North West direction. The dip amount is $58^{\circ}$ and dip direction is $\mathrm{N} 290^{\circ}$ towards North West. Preliminary investigation indicates the possibility of planar failure. Two failures have been reported in the year 2010. Increase in water absorption content in soils and a toe cutting has triggered the landslides in Assar [16]. Repeated slumping is experienced in this location. The textural analyses of soil indicate that the silt+clay content is $25 \%$ and coarser fraction constitute of $75 \%$. The friction angle determined as $20.50^{\circ}$. The liquid limit and plastic limit is determined as 5.5 and 40.50 respectively. High coarser fraction in soil indicate low Cohesion and friction angle. One of the causative factors that triggered slump includes the increase in water absorption content of the soil.

\subsection{Chengara (M01)}

Chengara is located in Malapuram district of Kerala. Land degradation in the form of soil slump had caused extensive damage to rubber plantation covering an area of 3 acres in 1994. Another major slump occurred on $17^{\text {th }}$ July 2007. The features of the failed slopes are given in the table. Cracks have been developed across and parallel to slope faces with a width of $1 / 2 \mathrm{~m}$ to $2-1 / 2$ the overlying soil failed along an arcuate surface and caused flattening of well casing. The top water saturated soil horizon has separated from underlying impervious crystalline rocks and slumped down slope by its own weight. The crystalline rock in this area is chiefly granite gneisses. Plasticity of the soil is high. 15 houses are situated at the foot of the slope. Palaeoslides have been reported from the area. Construction on the rain pits on the slope was the main factor for the initiation of the landslip in 1994. The slope is characterised by two generation of rubber plantations. Age of trees in one sector is 12 years and the plants in the adjacent sector have growth 1 - 11/2 years. The landslip has occurred only in the sector where plants are young. Deep cracks have been developed in the adjacent sector and slumping of soil is prevented by the deeper root system of the older rubber plants. The recent terracing done on the slopes in younger plantation sector has prevented the runoff and excess water collected on flat terraces percolates as subsurface seepage into the thick soil column overlying the impervious crystalline rocks. This developed a temporary water table and increases the water head. The rise in peiziometric head increased the pore water pressure and decreased shearing resistance causing the arcuate failure along the plane of contact.

\subsection{Akamala (T01)}

Akamala is located in Thrissur District of Kerala. Akamala disaster struck on $5^{\text {th }}$ June 2004 in a reserved forest area 


\section{International Journal of Science and Research (IJSR) \\ ISSN (Online): 2319-7064 \\ Index Copernicus Value (2013): 6.14 | Impact Factor (2014): 5.611}

which causes extensive damage to forest land. Casualities were avoided as the settlements were a few meters away from the rolled down slide debris. Akamala hill slope profile form part of a reserved forest. The maximum elevation is $320 \mathrm{~m}$ and the lowest elevation is $80 \mathrm{~m}$ from MSL. The profile is at the western plank of the NW-SE trending ridge. Head scarp of this slide is shallow $(0.5 \mathrm{~m}$ depth) and the width increases up to $15 \mathrm{~m}$ at the base and attain maximum depth up to $1.6 \mathrm{~km}$. lithologically it is composed of gneissic charnockite and sub areal weathering has resulted laterites and highly weathered rocks of varying thickness. The forest is degraded to a certain extend. The analysis indicated that in akamala profile wedge failure occurred along the intersection of joints $30 \mathrm{~N}$ 315and $70 \mathrm{~N} 80$ falls within the crescent shaped shaded area (Figure 2b). Chances of plane failure along the joints $30 \mathrm{~N} 315$ also exist in this location.

\subsection{Kunjithanni (I01)}

Kunjithanni is located in Idukki District of Kerala. The debris flow occurred at 8:40 pm on $4^{\text {th }}$ August 2013. The failed area is situated very close to the natural drain, which is ephemeral with a width of $2 \mathrm{~m}$, lies between the destructed house and partially damaged building complex. Granitic gneiss is the chief rock type and the thickness of the over burden is $2-3 \mathrm{~m}$. The rock is rich in coarse pink feldspar and contains subordinate amount of ferromagnesium minerals. Veins of quartz are observed. The toe of the slide scar is at a height of $801 \mathrm{~m}$ and the distance from the toe to the crown is is $700 \mathrm{~m}$. As a result of the debris flow a house was totally collapsed and two people died. Indication of slope modification was observed at the top part of the scar. The slope is vegetated with shallow rooted trees such as cardamom, coffee and pepper. The width of the crown is $5 \mathrm{~m}$ and it widens up to $35 \mathrm{~m}$ as it reaches the toe. The slope of the hill is $60^{\circ}$ dipping towards $\mathrm{N} 60^{\circ}$. Joints present in the hard rock ${ }^{\text {ee }} \mathrm{s}$ got exposed by mass wasting process. Four joints with the trend of $\mathrm{J} 1$ is repeated in the area. The friction angle determined in geo technical lab is $22^{\circ}$. $\mathrm{J} 1$ and $\mathrm{J} 3$ acted as the failure surfaces and the intersection of these joints fall within the crescent shaped portion. The debris flow occurred along the direction N 26. This is categorized as a typical wedge failure (Figure 2c).

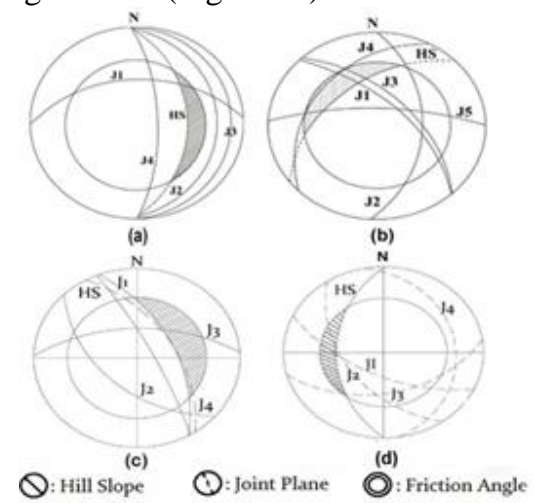

Figure 2a, b, c and d: Stereographic Projection of Joints and their relationship with the material properties and hill slope

\subsection{Methottimala (I02)}

Methottimala is located in Idukki District Kerala. Two houses were destroyed and agricultural damage was caused by debris flow on $4^{\text {th }}$ August 2013. Main cultivation includes tapioca, plantain and coconut. A raised metal road across the valley which partially submerges under flood season, with $29 \mathrm{~m}$ length and $3 \mathrm{~m}$ width was washed off by the hitting impacts of large boulders. The chief rocktype of the area is granitic gneiss. Thickness of soil is about $3 \mathrm{~m}$. Two debris flows united and flowed down slope. The crown of the scar is having a width of 3 $\mathrm{m}$, attains $29 \mathrm{~m}$ in the middle part and runs for $1 \mathrm{~km}$ downhill. Dip of the hill slope is N270. The discontinuities have no role in this disaster. Chance of toppling still exist in the area according to the figure $2 \mathrm{~d}$.

Table 2: Characteristic features of the hill slope

\begin{tabular}{|c|c|c|c|c|c|c|c|}
\hline Locations & $\begin{array}{c}\text { Hill Slope } \\
\text { (in degerees) }\end{array}$ & Joints & $\begin{array}{c}\text { Nature of } \\
\text { slope failure }\end{array}$ & Slope Material & $\begin{array}{c}\text { Friction } \\
\text { Angle } \\
\end{array}$ & Height & $\begin{array}{c}\text { Relative } \\
\text { Relief }\end{array}$ \\
\hline Pasukkadavu (K01) & 48 N 90E & $\begin{array}{c}51 \mathrm{~N}\left(\mathrm{~J}_{1}\right) \\
32 \mathrm{~N} 90\left(\mathrm{~J}_{2}\right) \\
22 \mathrm{~N} 90\left(\mathrm{~J}_{3}\right) \\
80 \mathrm{~N} 90\left(\mathrm{~J}_{3}\right) \\
\end{array}$ & Debris flow & $\begin{array}{l}\text { Highly weathered } \\
\text { granitic gneiss }\end{array}$ & $34^{\circ}$ & $775 \mathrm{~m}$ & $475 \mathrm{~m}$ \\
\hline Kakkayam (K02) & $50^{\circ} \mathrm{N} 315^{\circ}$ & $58^{0} \mathrm{~N} 290$ & Slump & $\begin{array}{c}\text { Laterite + granitic } \\
\text { gneiss }\end{array}$ & $20.50^{\circ}$ & & $245 \mathrm{~m}$ \\
\hline Chengara (M01) & $54^{\circ} \mathrm{N} 300^{\circ}$ & - & Slump & $\begin{array}{l}\text { Laterite + granitic } \\
\text { gneiss }\end{array}$ & $22^{\circ}$ & $228 \mathrm{~m}$ & $168 \mathrm{~m}$ \\
\hline $\begin{array}{l}\text { Akamala } \\
\text { (T01) }\end{array}$ & $40^{\circ} \mathrm{N} 310^{\circ}$ & $\begin{array}{c}70^{\circ} \mathrm{N} 45(\mathrm{~J} 1) \\
50^{\circ} \mathrm{N} 95(\mathrm{~J} 2) \\
70^{\circ} \mathrm{N} 48(\mathrm{~J} 3) \\
\text { N } 315(\mathrm{~J} 4) \\
80^{\circ} \mathrm{N}(\mathrm{J} 5)\end{array}$ & Debris flow & $\begin{array}{l}\text { Gneissic } \\
\text { charnockite, } \\
\text { Laterite }\end{array}$ & $29^{\circ}$ & $320 \mathrm{~m}$ & $240 \mathrm{~m}$ \\
\hline Kunjithanni (I01) & $60^{\circ} \mathrm{N} 60^{\circ}$ & $\begin{array}{l}60^{\circ} \text { N65 (J1), } \\
80^{\circ} \text { N65 (J2), } \\
55^{\circ} \text { N360( J3), } \\
60^{\circ} \text { N220( J4) }\end{array}$ & Debris flow & $\begin{array}{l}\text { Weathered granitic } \\
\text { gneiss }\end{array}$ & $22^{\circ}$ & $801 \mathrm{~m}$ & $210 \mathrm{~m}$ \\
\hline Methottimala (I02) & $\mathrm{N} 270^{\circ}$ & $\begin{array}{c}60^{\circ} \mathrm{N} 210(\mathrm{~J} 1), \\
50^{\circ} \mathrm{N} 240(\mathrm{~J} 2), \\
40 \text { N170(J3), } 20 \\
\text { N80(J4) }\end{array}$ & Debris flow & $\begin{array}{l}\text { Weathered granitic } \\
\text { gneiss }\end{array}$ & $26^{\circ}$ & $450 \mathrm{~m}$ & $400 \mathrm{~m}$ \\
\hline
\end{tabular}




\section{International Journal of Science and Research (IJSR) \\ ISSN (Online): 2319-7064}

Index Copernicus Value (2013): 6.14 | Impact Factor (2014): 5.611

\section{Rainfall as a Triggering Factor}

The earlier studies indicate that $180 \mathrm{~mm}$ rainfall for couple of days can be considered as a threshold value to alert the civic administration to get set for disaster management measures [12]. When dry season is followed by monsoon rainfall, the cohesive strength of soil and weathered rocks overlying the hard compact rock is reduced, loosened enough to move down slope when incessant short spell of rainfall coincides. At the onset of monsoon, copious rainfall was experienced and during this wet spell, the water infiltrated very quickly to deeper level in the hill slope than would otherwise occur. The presence of soil water also increased pore water pressure and water which is relatively incompressible so acted to push the soil grains apart. This decreases the soil strength. The resistant strength to shear decreases and reduction in stiffness due to volume changes can contribute very significantly to slope failure. In locations K01, I01, I02 and T01 the influence of joint planes are revealed. The role of bed rock fractures and groundwater accumulation in relation to landslides and debris flows was well reviewed by [6] in metamorphic and sedimentary terrains and by [8] in granitic terrains. The joint planes acted as a channel ways for the percolation of rain water and consequently reducing the factor of safety.

The slope failure occurred when the minimum amount of rainfall for 7 days (including the day of incidence) was $167.41 \mathrm{~mm}$ (Table 3 and Figure 3). The minimum amount of rainfall required for slope failure for 3 days was estimated to be $101.33 \mathrm{~mm}$. On other hand the minimum threshold for slope failure was $101.21 \mathrm{~mm}$ when penultimate 6 days of the disaster is considered. Storms that produce intense rainfall for periods as short as several hours or have a more moderate intensity lasting several days have triggered number of landslides [11].

Table 3: Rainfall received ( $\mathrm{mm}$ ) preceding 6 days and day of the event

\begin{tabular}{|c|c|c|c|c|c|c|c|}
\hline & Day 1 & Day 2 & Day 3 & Day 4 & Day 5 & Day 6 & Day 7 \\
\hline Pasukkadavu (K 1) & 13.2 & 43 & 2.8 & 2.4 & 63.6 & 175.2 & 54 \\
\hline Kakkayam (K 2) & 34.51 & 22.19 & 5.27 & 4.14 & 10.36 & 24.77 & 66.20 \\
\hline Chengara (M 1) & 62 & 19 & 50 & 18 & 10 & 59 & 85 \\
\hline Akamala (T 1) & - & 22.5 & 60.5 & - & 12.5 & 27.8 & 120 \\
\hline Kunjithanni (I 1) & 1.0 & 1.1 & 35.5 & 102 & 47.1 & 96.1 & 228 \\
\hline Methottimala (I 2) & 35.5 & 102 & 47.1 & 96.1 & 228 & 95.8 & 40.5 \\
\hline
\end{tabular}

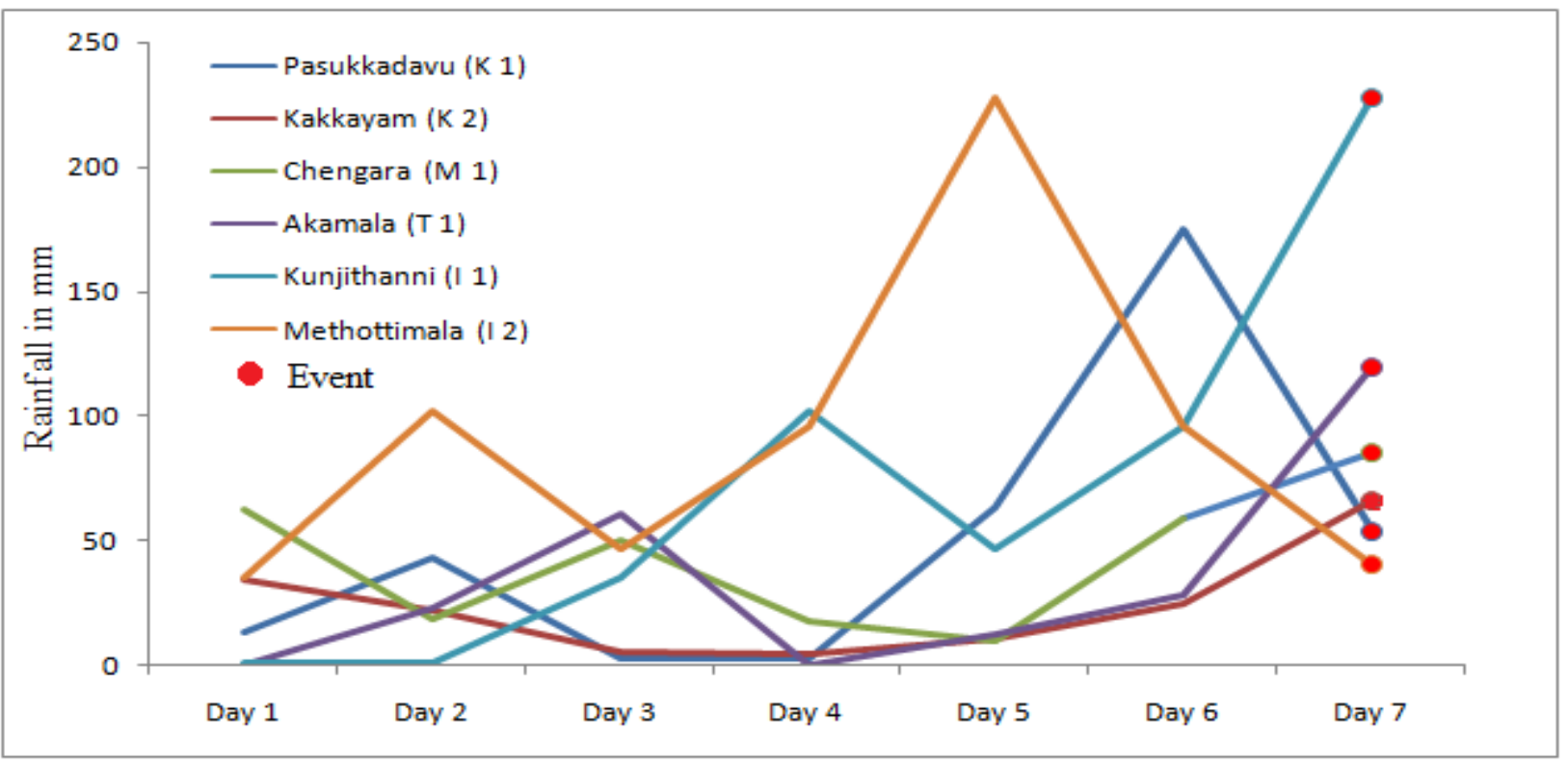

Figure 3: Graph showing rainfall in mm

\section{Conclusion}

The natural factors such as steepness of hill slope, relative relief, thickness of the overburden, attitude of joints and fracture in rock, hydraulic conductivity and less coherent nature of the overburden make the slope vulnerable to slope failures. The shallow rooted trees, agricultural practices in hill slope also have contributed in increasing the dimension of debris flow and consequent damage. The continuous and copious rainfall on the day of the event and penultimate days acted as the catalyst for triggering slope failures.
The reasons for the slope failure are found to be site specific. Majority of the debris flows in Pasukkadav, Kunjithanni, Methotti mala and Akamala located close to the proximity of first order ephimeral streamlets. Continuous rainfall for the couple of days acted as the trigger force for the onset of the failure. The homogeneity of geotechnical properties such as cohesion, friction angle and hydraulic conductivity of the overburden and huge thickness might have resulted debris flows. In most of the debris flow reported the overburden has detached along the contact of intact hard rock and the upper overburden. The cumulative effect of pore water pressure along the 


\section{International Journal of Science and Research (IJSR) \\ ISSN (Online): 2319-7064 \\ Index Copernicus Value (2013): 6.14 | Impact Factor (2014): 5.611}

potential failure surface such as joints and fractures, the buoyant force developed because of excess water percolation during the continuous spell of rainy days can be cited as the main contributing parameters for the onset of series of debris flow in this area.

\section{Acknowledgement}

We are thankful to University Grants Commission, India for the financial assistance to carry out the project.

\section{Reference}

[1] M.D. Gidigasu, General report: "Geomechanics in tropical soils". Proceedings of the Second International Conference on Geomechanics in Tropical Soils, Singapore, 2, pp. 495-504, 1990.

[2] E. Hoek and J.W. Bray, Rock slope engineering, the Institution of Mining and Mettalurgy, London, 358 p, 1981.

[3] J.N. Hutchinson, A coastal mudflows on the London clay cliffs at Belting North Kent, Geotechnique, 20, pp. 412-438. 1970.

[4] V.C. Jacob, Landslide prone areas of Kerala. (Abstract). National Seminar on Landslides Western Ghats (Abstract), Thiruvananthapuram, pp. 2, 1995

[5] R. Krishnanath, "Identification and location of landslide prone areas, Proc. Workshop on landslides in Western Ghats, Calicut", State committee for Science Technology and Environment, Thiruvananthapuram, pp. 1-11, 1985.

[6] C.C. Mathewson, J.R. Keaton, P.M. Santi, "Role of bedrock groundwater in the initiation of debris flow and sustained postflow stream discharge". Bull Assoc Engineering Geology 27(1). pp. 73-83, 1990.

[7] H.F.H.M. Mulder, T.W.J. Van Asch, "On nature and magnitude of variance of important geotechnical parameters", Proc. Vth Int. Nat. Symp. on landslides, Balkema, V.1, pp. 239- 250, 1988.

[8] Y. Onda, "Hill slope hydrology and and mass movements in the Japanese Alps." In: Owens P N. Slaymaker O (Ed) Mountain Geomorphology, pp. 164, 2004.

[9] S. Sarkar, Pravin K Gupta, "Techniques for Landslide Hazard Zonation- Application to SrinagarRudraprayag area of Garhwal Himalaya”, Journal of Geological Society of India, Vol 65, pp. 217-230, 2005.

[10] V.K. Sharma, "Macro-zonation of landslide hazard in the environs of Baira Dam Project, Chamba District, Himachal Pradhesh", Journal Geological Society of India, Vol 71, pp. 425-435, 2008.

[11] S. Sreekumar, R. Krishnanath, "Geometric analysis of certain certain rock slope profile in Idukki District, Kerala State". Proc.Seminar on Landslides in Western Ghats, CESS, Thiruvananthapuram, pp. 12, 1995.

[12]S. Sreekumar, Geotechnical and petrological studies of slopes along the Kottayam-Kumili road, Kerala state, India. PhD thesis (unpublished), submitted to the University of Kerala, Trivandrum, India. 1998.

[13] S. Sreekumar, R. Krishnanath, "Stability of laterite profile in parts of Western Ghat, India”. In: landslides research: theory and practice, $\mathrm{V} 3$, Thomas Telford, London, pp. 1400, 2000.

[14] Sreekumar S(2009) "Techniques for slope stability analysis: site specific studies from Idukki District, Kerala ${ }^{\text {eece }}$. Journal of the Geological Society of India, V 73. No 6, pp 813-820.

[15]K. Terzaghi, Mechanism of Landslides. Geological Society of America, Berkey volume, pp. 123, 1950.

[16] Yudhbir sing, G.M. Bhat, Vinay Sharma, S.K. Pandita, K.K, "Thakur Resevoir induced landslide at Assar, Jammu and Kashmir: A case study". Journal Geological Society of India, Vol 80, pp. 435-439, 2012

\section{Author Profile}

Arish Aslam is a Research Scholar, Department of Geology and Environmental Science, Christ College, Irinjalakuda- 60125, Kerala, India.

Dr. S. Sreekumar is Associate Professor in Department of Geology and Environmental Science, Christ College, Irinjalakuda- 60125, Kerala, India. Dr. S Sreekumar has been awarded doctoral degree in Geology by the University of Kerala in 1999. He coordinated several major research projects on Identification and location of slide prone areas in Kerala Western Ghats and Geo environmental issues of Kole wetlands in Kerala, India 